\title{
When Academic Debate Meets Translation Decisions: The English Translations of Pistis Christou as an Example
}

\author{
Chun Li \\ Bethel Bible Seminary, Hong Kong
}

The Pistis Christou Debate is still one of the most discussed problem in New Testament studies. The heated debate about whether to translate the term Pistis Christou as subjective genitive or objective genitive has been going on among scholars for over a century. The current debate can be traced back to Johannes Hauflleiter's paper in 1891, or even earlier (Schliesser, 2015). It is said that "new publications continue to flood the market" (Easter, 2010, 33-37).

While the Pistis Christou debate is going on, new English translations of the Bible have appeared in the past 20 years. Biblical scholars and theologians could continue to engage in the debate while translators of the new versions would have to decide which position was to be reflected in their new translation. The current paper aims at looking at the Pistis Christou debate and exploring how new translations incorporate the discussions as so far provided by scholars.

\section{The Pistis Christou Debate}

The Pistis Christou debate refers to the discussion about whether to interpret pistis Christou as an objective genitive or a subjective genitive. Usually, the former will be translated as "faith in Christ" and the latter as "faithfulness of Christ". Easter (2010, p.33) called the former the 'anthropological' reading and the latter the 'christological' reading. The arguments of both sides can be categorized as lexical, grammatical and theological (Hunn, 2010). 


\section{Lexical Issues}

In early discussion of the issue involved, Gabriel Hebert and T. F. Torrance tended to import the meaning of the word from Greek or Hebrew tradition. This approach has been refuted by James Barr. Recently, there were attempts to import meanings such as obedience, righteousness, "fidei commissum" into the word pistis. However, these approaches also did not receive wide acceptance. (Hunn, 2010, p. 17-18)

Most common translations of pistis Christou would render pistis as either "faith" or "faithfulness". While the objective genitive camp would agree on translating pistis as "faith", the subjective camp could translate pistis as either "faith" or "faithfulness". However, most of the discussion for the subjective genitive position would argue for translating the term as "faithfulness" rather than "faith". Scholars also tried to investigate how pistis was used in the Septuagint and Jewish Hellenistic Greek. Some even tried to derive the meaning of pistis from its cognate pisteuw. As informative as this kind of research could be, its value for determining the meaning of pistis Christou is questionable. (Hunn, 19-20)

\section{Grammatical Issues}

Most of the discussion about the pistis Christou debate fell into the grammatical category. There were discussions about the presence or absence of the definite article before pistis as a pointer towards the meaning of pistis. It has been argued that when pistis has a definite article, it is subjective, but if it does not have an article, then it should be read as objective. However, most scholars recently would reject the approach of determining the meaning of pistis just by the absence or presence of the definite article. (Easter, 2010, p.34)

Another direction for discussion was along the syntactical path. George Howard examined Paul's use of the word pistis with genitive of person or personal pronouns other than Christou, and found that 24 times the genitive was subjective rather than objective. The legitimacy of reading these usages into the phrase pistis Christou has been challenged. The highest count in the literature should not substitute the importance of the context for determining the meaning of a phrase.

William Loader, Boris Repschinski, Eric Wong (Eds.)

Matthew, Paul, and Others: Asian Perspectives on New Testament Themes

(C) 2019 innsbruck university press, ISBN 978-3-903187-66-5, DOI 10.15203/3187-66-5 
The common argument for the Christological camp is the redundancy created by the anthropological reading in Rom 3:22. It is said that the objective reading would render the following part of the sentence (to all who believe) redundant. However, the alleged redundancy in the repetition can be viewed as intentional and reflect Paul's emphasis on the role of believers' faith in Christ.

Another way to look at the issue is to explore the usage of pistis en Christõ. The use of the preposition en is not a Pauline idiom and therefore he resorts to pistis Christou. Other scholars looked into the phrase ek pisteõs and hoped to find out the meaning of pistis Christou from the various phrases mentioned above. The results of these comparisons have been inconclusive, and scholars would point out that these grammatical discussions can hardly be the only reasons for adopting either objective or subjective understanding of the phrase. Indeed, the "larger reading of Paul's theology" should be the determining factor in choosing the interpretation (Easter, 2010, p. 44).

\section{Theological Issues}

Herbert pointed out that the objective reading of pistis Christou is too weak an argument in Romans to counteract the Jewish view of justification. The Christological reading would be more adequate. The subjective reading would help to emphasis the role of Christ in contrast to the Jewish view. But van Daalen is reasonable to say that when someone has faith in another person, the other person has the quality that can be relied. This is also an adequate argument against Jewish interpretation. (Hunn, 2010, p. 27)

Since pistis Christou is often contrasted with "works of law", the theological meaning of these two phrases are compared. The anthropological side argues that since works of law refers to human actions, pistis Christou as its counterpart should also be read from an anthropological perspective. For the Christological camp, since works of the law refers to human actions, the contrasting pistis Christou should be read as God's action. (Easter, 2010, p. 27)

When Benjamin Schliesser (2015, p. 89) reviewed the history of interpretation, he found that their theological commitment has always been a key factor in determining the interpreters' position:

"Historical hindsight also opens the eyes to the correlation of theological commitment and exegetical conclusions. To be sure, one should beware of simplistic and premature classifications, but is it by accident that the rationalist

William Loader, Boris Repschinski, Eric Wong (Eds.)

Matthew, Paul, and Others: Asian Perspectives on New Testament Themes

(C) 2019 innsbruck university press, ISBN 978-3-903187-66-5, DOI 10.15203/3187-66-5 
Jesus Christ of Paulus and Schulthel is understood as a moral-religious model, as a prime example of a desirable 'sincerity of conviction' ? That the mysticalspeculative Jesus Christ of Benecke is characterized by his 'unceasing faithful agency', which restores the relationship between the estranged human nature and God? That the Dutch reformed Jesus Christ of Berlage underlines the total dependence of human beings on God in that Christ alone is the origin, cause, and author of our faith in God? Finally, that in the 'dialectical' Jesus Christ of Barth God's faithfulness became a (historical) event, a movement from heaven to earth, which brings back all that has been lost to the world and to humanity due to their distance from God?"

It is not surprising that the theological commitment has its place in scholars' discussion. The position taken by a scholar may be determined by the academic investigation, but it is also very possible that the theological commitment has a place too. For the review of translations, the theological positions and the denominational standing should also be considered.

\section{The Translations Used for Comparison}

There have been many new English translations of the Bible in the past two decades. The current paper reviews two categories of translations. The first category is the that of most popular or preferred translations including the King James (KJV) and its modernized version the New King James Version (NJV), the New International Version(NIV) and the English Standard Version (ESV). The King James Version is still the esteemed and preferred English version in USA. The next most preferred or popular versions have been NIV and ESV. (Silliman, 2015) The top three versions used in the last five years have been KJV, NIV and ESV in Barna Group survey in USA. (http://www.barna.com)

Another category comprises those which have been published within the past 20 years. Theses relatively new versions include: New Living Translation (NLT), World English Bible (WEB), The Message((MSG), New English Translation(NET), and Common English Bible(CEB). Those in this category are not only recently-released translations, but also representing a new form of versions in different perspectives. For example, NLT is based on the dynamic equivalence rationale and seeks to convey the thoughts behind the text. This can be seen as representing thought-for-thought translation. The WEB is a free updating of the American Standard Version which is also a public domain

William Loader, Boris Repschinski, Eric Wong (Eds.)

Matthew, Paul, and Others: Asian Perspectives on New Testament Themes

(C) 2019 innsbruck university press, ISBN 978-3-903187-66-5, DOI 10.15203/3187-66-5 
version. This means the copyright has been waived and it is free for all to use. The Message is the translation by Eugene Peterson. The NET is a translation done by scholars tailored to be used online. The CEB aimed at producing a new translation for all English readers at a comfortable level. These versions are chosen to illustrate how the translation of Pistis Christou can be manifested in different versions.

\section{Translations of Pistis Christou}

\begin{tabular}{|c|c|c|c|c|c|c|c|c|c|}
\hline & $\begin{array}{l}\text { KJV } \\
(1611)\end{array}$ & $\begin{array}{l}\text { NIV } \\
(1978)\end{array}$ & $\begin{array}{l}\text { NKJ } \\
(1982)\end{array}$ & $\begin{array}{l}\text { WEB } \\
(2000)\end{array}$ & $\begin{array}{l}\text { ESV } \\
(2001)\end{array}$ & $\begin{array}{l}\text { MSG } \\
(2002)\end{array}$ & $\begin{array}{l}\text { NET } \\
(2005)\end{array}$ & $\begin{array}{l}\text { CEB } \\
(2011)\end{array}$ & $\begin{array}{l}\text { NLT } \\
(2015)\end{array}$ \\
\hline $\begin{array}{l}\text { Rom } \\
3: 22\end{array}$ & $\begin{array}{l}\text { faith of } \\
\text { Jesus } \\
\text { Christ }\end{array}$ & $\begin{array}{l}\text { faith in } \\
\text { Jesus } \\
\text { Christ }\end{array}$ & $\begin{array}{l}\text { faith in } \\
\text { Jesus } \\
\text { Christ }\end{array}$ & $\begin{array}{l}\text { Faith in } \\
\text { Jesus } \\
\text { Christ }\end{array}$ & $\begin{array}{l}\text { faith in } \\
\text { Jesus } \\
\text { Christ }\end{array}$ & $\begin{array}{l}\text { Jesus- } \\
\text { setting- } \\
\text { things- } \\
\text { right }\end{array}$ & $\begin{array}{l}\text { Faithfulne } \\
\text { ss of Jesus } \\
\text { Christ }\end{array}$ & $\begin{array}{l}\text { faith- } \\
\text { fulness of } \\
\text { Jesus } \\
\text { Christ }\end{array}$ & $\begin{array}{l}\text { faith in } \\
\text { Jesus } \\
\text { Christ }\end{array}$ \\
\hline $\begin{array}{l}\text { Rom } \\
3: 26\end{array}$ & $\begin{array}{l}\text { believeth } \\
\text { in Jesus }\end{array}$ & $\begin{array}{l}\text { faith in } \\
\text { Jesus } \\
\text { Christ }\end{array}$ & $\begin{array}{l}\text { faith in } \\
\text { Jesus }\end{array}$ & $\begin{array}{l}\text { Faith in } \\
\text { Jesus }\end{array}$ & $\begin{array}{l}\text { faith in } \\
\text { Jesus }\end{array}$ & $\begin{array}{l}\text { to live in } \\
\text { his } \\
\text { rightness }\end{array}$ & $\begin{array}{l}\text { Jesus' } \\
\text { faith- } \\
\text { fulness }\end{array}$ & $\begin{array}{l}\text { Faith in } \\
\text { Jesus as } \\
\text { righteous }\end{array}$ & $\begin{array}{l}\text { they } \\
\text { believe in } \\
\text { Jesus }\end{array}$ \\
\hline $\begin{array}{l}\text { Gal } \\
2: 16\end{array}$ & $\begin{array}{l}\text { faith of } \\
\text { Jesus } \\
\text { Christ }\end{array}$ & $\begin{array}{l}\text { faith in } \\
\text { Jesus } \\
\text { Christ }\end{array}$ & $\begin{array}{l}\text { faith in } \\
\text { Jesus } \\
\text { Christ }\end{array}$ & $\begin{array}{l}\text { Faith in } \\
\text { Jesus } \\
\text { Christ }\end{array}$ & $\begin{array}{l}\text { faith in } \\
\text { Jesus } \\
\text { Christ }\end{array}$ & $\begin{array}{l}\text { Personal } \\
\text { faith in } \\
\text { Jesus } \\
\text { Christ }\end{array}$ & $\begin{array}{l}\text { Faith- } \\
\text { fulness of } \\
\text { Jesus } \\
\text { Christ }\end{array}$ & $\begin{array}{l}\text { Faith- } \\
\text { fulness of } \\
\text { Jesus } \\
\text { Christ } \\
\end{array}$ & $\begin{array}{l}\text { we have } \\
\text { believed } \\
\text { in Christ } \\
\text { Jesus }\end{array}$ \\
\hline $\begin{array}{l}\text { Gal } \\
2: 20\end{array}$ & $\begin{array}{l}\text { the faith } \\
\text { of the Son } \\
\text { of God }\end{array}$ & $\begin{array}{l}\text { faith in } \\
\text { the Son of } \\
\text { God }\end{array}$ & $\begin{array}{l}\text { faith in } \\
\text { the Son of } \\
\text { God }\end{array}$ & $\begin{array}{l}\text { Faith in } \\
\text { the Son of } \\
\text { God }\end{array}$ & $\begin{array}{l}\text { faith in } \\
\text { the Son of } \\
\text { God }\end{array}$ & $\begin{array}{l}\text { faith in } \\
\text { the Son of } \\
\text { God }\end{array}$ & $\begin{array}{l}\text { Faith- } \\
\text { fulness of } \\
\text { the son of } \\
\text { God }\end{array}$ & $\begin{array}{l}\text { The faith- } \\
\text { fulness of } \\
\text { God's } \\
\text { Son }\end{array}$ & $\begin{array}{l}\text { trusting in } \\
\text { the Son of } \\
\text { God }\end{array}$ \\
\hline $\begin{array}{l}\text { Gal } \\
3: 22\end{array}$ & $\begin{array}{l}\text { faith of } \\
\text { Jesus } \\
\text { Christ }\end{array}$ & $\begin{array}{l}\text { faith in } \\
\text { Jesus } \\
\text { Christ }\end{array}$ & $\begin{array}{l}\text { faith in } \\
\text { Jesus } \\
\text { Christ }\end{array}$ & $\begin{array}{l}\text { Faith in } \\
\text { Jesus } \\
\text { Christ }\end{array}$ & $\begin{array}{l}\text { faith in } \\
\text { Jesus } \\
\text { Christ }\end{array}$ & $\begin{array}{l}\text { (faith for } \\
\text { God to } \\
\text { complete } \\
\text { his } \\
\text { promise) }\end{array}$ & $\begin{array}{l}\text { Faith- } \\
\text { fulness of } \\
\text { Jesus } \\
\text { Christ }\end{array}$ & $\begin{array}{l}\text { Faith- } \\
\text { fulness of } \\
\text { Jesus } \\
\text { Christ }\end{array}$ & $\begin{array}{l}\text { believing } \\
\text { in Jesus } \\
\text { Christ }\end{array}$ \\
\hline $\begin{array}{l}\text { Phil } \\
3: 9\end{array}$ & $\begin{array}{l}\text { faith of } \\
\text { Christ }\end{array}$ & $\begin{array}{l}\text { faith in[a] } \\
\text { Christ } \\
\text { Or } \\
\text { through } \\
\text { the faith- } \\
\text { fulness of }\end{array}$ & $\begin{array}{l}\text { faith in } \\
\text { Christ }\end{array}$ & $\begin{array}{l}\text { Faith in } \\
\text { Christ }\end{array}$ & $\begin{array}{l}\text { faith in } \\
\text { Christ }\end{array}$ & $\begin{array}{l}\text { trusting } \\
\text { Christ }\end{array}$ & $\begin{array}{l}\text { Christ's } \\
\text { faith- } \\
\text { fulness }\end{array}$ & $\begin{array}{l}\text { Faith- } \\
\text { fulness of } \\
\text { Christ }\end{array}$ & $\begin{array}{l}\text { faith in } \\
\text { Christ. }{ }^{[\mathrm{a}]} \\
\text { Or } \\
\text { through } \\
\text { the faith- } \\
\text { fulness of } \\
\text { Christ }\end{array}$ \\
\hline $\begin{array}{l}\text { (Eph } \\
3: 12)\end{array}$ & $\begin{array}{l}\text { faith of } \\
\text { him }\end{array}$ & $\begin{array}{l}\text { Faith in } \\
\text { him }\end{array}$ & $\begin{array}{l}\text { Faith in } \\
\text { him }\end{array}$ & $\begin{array}{l}\text { Faith in } \\
\text { him }\end{array}$ & $\begin{array}{l}\text { Faith in } \\
\text { him }\end{array}$ & $\begin{array}{l}\text { trust in } \\
\text { him }\end{array}$ & $\begin{array}{l}\text { Christ's } \\
\text { faith- } \\
\text { fulness }\end{array}$ & $\begin{array}{l}\text { Faith in } \\
\text { him } \\
\text { Or } \\
\text { through } \\
\text { his faith- } \\
\text { fulness }\end{array}$ & $\begin{array}{l}\text { Faith in } \\
\text { him }\end{array}$ \\
\hline
\end{tabular}

NET (https://netbible.org) has the following study notes and translation notes after Rom 3.22, the translation notes also appear in Gal 2:16 and Phil 3:9:

William Loader, Boris Repschinski, Eric Wong (Eds.)

Matthew, Paul, and Others: Asian Perspectives on New Testament Themes

(C) 2019 innsbruck university press, ISBN 978-3-903187-66-5, DOI 10.15203/3187-66-5 
sn ExSyn 116, which notes that the grammar is not decisive, nevertheless suggests that "the faith/faithfulness of Christ is not a denial of faith in Christ as a Pauline concept (for the idea is expressed in many of the same contexts, only with the verb $\pi 1 \sigma \tau \varepsilon v$ w rather than the noun), but implies that the object of faith is a worthy object, for he himself is faithful." Though Paul elsewhere teaches justification by faith, this presupposes that the object of our faith is reliable and worthy of such faith.

tn Or "faith in Christ." A decision is difficult here. Though traditionally translated "faith in Jesus Christ," an increasing number of NT scholars are

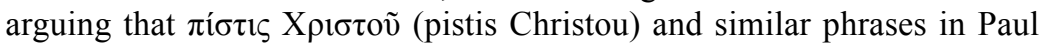
(here and in v. 26; Gal 2:16, 20; 3:22; Eph 3:12; Phil 3:9) involve a subjective genitive and mean "Christ's faith" or "Christ's faithfulness" (cf., e.g., G. Howard, "The 'Faith of Christ'," ExpTim 85 [1974]: 212-15; R. B. Hays, The Faith of Jesus Christ [SBLDS]; Morna D. Hooker,

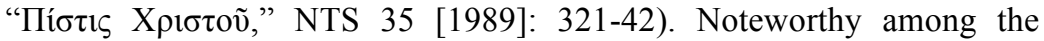

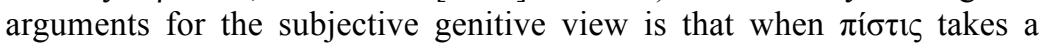
personal genitive it is almost never an objective genitive (cf. Matt 9:2, 22, 29; Mark 2:5; 5:34; 10:52; Luke 5:20; 7:50; 8:25, 48; 17:19; 18:42; 22:32; Rom $1: 8 ; 12 ; 3: 3 ; 4: 5,12,16 ; 1$ Cor $2: 5 ; 15: 14,17 ; 2$ Cor 10:15; Phil 2:17; Col 1:4; 2:5; 1 Thess $1: 8 ; 3: 2,5,10 ; 2$ Thess $1: 3$; Titus $1: 1$; Phlm 6; 1 Pet $1: 9,21 ; 2$ Pet $1: 5)$. On the other hand, the objective genitive view has its adherents: A. Hultgren, "The Pistis Christou Formulations in

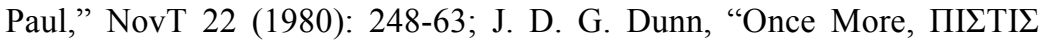

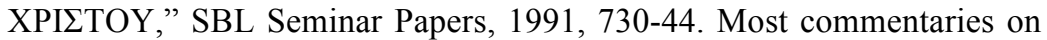
Romans and Galatians usually side with the objective view."

\section{Observations from Comparing the pistis Christou Translations}

\section{The "Re-emergence" of the Subjective Genitive Translation}

It should be noted that the KJV adopted "faith of Christ" as the translation of pistis Christou in the selected passage except in Rom 3:26. After KJV, the NIV, NKJ and ESV all rendered similar terms as "faith in Christ" in all the selected verses. As we have mentioned before, the KJV, NIV and ESV were the most popular versions. ESV came from a family of translations derived from RSV (similar translations include NRSV, NASB, etc.) These widely used translations 
all adopted the objective genitive interpretation of the term pistis Christou. It looks as if all have agreed on the objective use of it in all important passages and the KJV seems to be obsolete in its translation of the term.

Among the "relatively new" translations, the WEB followed the NIV and ESV to translate the genitive in as objective. NLT also translated the genitive in most of the verses as objective. The only subjective translation is in its footnote on Philippians 3:9 that says "faith in Christ" could be translated as "through the faithfulness of Christ".

MSG has tried to translate some of the verses as subjective and others as objective. For the MSG, "Jesus-setting-things-right" (Rom 3:22), "to live in his rightness" (Rom 3:26), "faith for God to complete his promise" (Gal 3:22) are renderings that convey the subjective sense in one way or another.

For the NET and CEB, all the verses surveyed in this research are translated in subjective sense. The only exception is Ephesians 3:12 as translated by CEB, which although translated as "faith in him" in the main text, also has a footnote stating that Ephesians 3:12 may also be translated "through his faithfulness". It can be said that NET and CEB are two translations that adopted the subjective interpretation.

The subjective sense translations were not uncommon in earlier translations, for example, the Wycliffe Bible (1382), the Darby translation (1890) and the Tyndale New Testament (1526) also translate Romans 3:26 as an objective genitive. The last one is a translation that the KJV translators relied on. In general, we can see that the KJV preference for the subjective sense has been rectified in the twentieth century's translations, resulting in the unanimous translation in the objective sense in NKJ, NIV, and ESV. These translations also represent the somewhat more popular versions among American readers (Zylstra, 2014).

However, as the discussion about pistis Christou became heated in the second half of the $20^{\text {th }}$ century, the subjective sense translation re-emerged as the "new trend" in translations. The MSG partially adopted the subjective sense and the NET and CEB were total supporters of the subjective interpretation.

\section{The Use of Footnotes}

As for the use of footnote to indicate possible translations other than the one in the main text, we have seen that not many translations include reference to 
alternative interpretations. After all, it is rare for a word to have both meanings at the same time. Hays pointed out that this would extend the problem of the meaning of pistis to include both meanings, so that pistis would include all other meanings and become unintelligible. Silva also pointed out that the context would make the meaning of the word clear (Hunn, 2010, p. 19).

We have found the most extensive footnotes in the NET bible, which is only possible given its design to be read on the internet. The elaborate discussion of scholars' debates and positions would be too copious for printed translations. The decision to explain a translation decision with regards to current scholarly discussion will also soon make the translations obsolete if the scholars' debate changes its course over time. However, for the NET Bible, this is made possible since its intention is to offer a translation online with footnotes available to all.

\section{Translations in Different texts}

It should be noted that nearly all translations adopted one interpretation across the different texts. Although context is said to be the most important factor in determining the meaning of the phrase, nearly all translations except the MSG adopt only one interpretation.

For scholars, the decision to adopt either the objective or the subjective approach not only involves the lexical and grammatical analysis as we have reviewed, it is also determined by (or is determining) the theological position of the scholar or translator. This factor should also be discussed alongside with the patronage factor as presented below.

\section{The Patronage Influence}

It should be noted that the relatively new translations that adopted the objective readings are those with linkage to translations in the $20^{\text {th }}$ century. The ESV is a revision of the Revised Standard Version (RSV, 1971) (Stec, 2004, p, 421). The WEB is a free updated revision of the American Standard Version(ASV), although it is in public domain. The volunteers rely on ASV (1901). The NLT is an updated version of the New Living Bible. It seems that the base texts for revisions have influence over the translations. All the above revisions adhere to the base text in choosing the objective interpretation. It is understandable that to adopt a different, if not contrasting, view to the base text would need a strong

William Loader, Boris Repschinski, Eric Wong (Eds.)

Matthew, Paul, and Others: Asian Perspectives on New Testament Themes

(C) 2019 innsbruck university press, ISBN 978-3-903187-66-5, DOI 10.15203/3187-66-5 
reason. The yet-to-be-settled debate of pistis Christou is not a solid ground for these versions to deviate from the objective interpretation of their base texts.

When we look into the translations that adopt the subjective interpretation, they are less dependent upon previous translations and can adopt the "new" subjective interpretation.

The CEB Bible is a new translation funded by the Church Resources Development Corp, which is a distinct corporation formed by the United Methodist Publishing House in Nashville, Tennessee. The committee is said to meet periodically and consists of denominational publishers from the Disciples of Christ, Presbyterian Church, Episcopal Church, United Church of Christ, and United Methodist Church (Dart, 2011).

NET Bible is also a new effort to provide a translation for readers through the internet. It is translated by 26 scholars but it welcomes comments and feedback from readers through the internet. This version aims at providing a translation for the public to use which minimizes the concern about copyright fees and infringements.

The Message is a one-man translation done by Eugene Peterson without clinging to any denomination. The nature of this translation makes it possible for less systematic treatment in the choice in translation. And it is understandable that the translator is free to choose whatever he thinks to be suitable to fit in the context of the text. There is no obligation to adhere to any denomination or theological camp. No doubt it is the only translation that adopts both the objective and subjective readings and applies different translations in different verses.

\section{Conclusions}

The pistis Christou debate is still a lively discussion point among Biblical scholars. The current paper has reviewed the main arguments of the debate and traced English translations' adaptation of the positions. The KJV adopted the subjective genitive position but is not followed by the major translations in the $20^{\text {th }}$ century. It is found that the translations in the $20^{\text {th }}$ century usually adopt the objective genitive interpretation as it was the widely accepted position in that era. The relatively new translations began to adopt the subjective interpretation. It should be noted that the translations that embrace the subjective interpretation

William Loader, Boris Repschinski, Eric Wong (Eds.)

Matthew, Paul, and Others: Asian Perspectives on New Testament Themes

(C) 2019 innsbruck university press, ISBN 978-3-903187-66-5, DOI 10.15203/3187-66-5 
are less connected to previous translations and have more freedom to choose the Christological approach.

Nearly all the translations adopt one position and apply it consistently, with the only exception of the MSG. This is reasonable as we have seen that choosing one position over another is not merely a grammatical consideration. The theological commitment does matter when it comes to this important phrase in Pauline theology. The MSG as a one-man translation can have more room to maneuver between different positions and can give more consideration to the context of each verse.

The NET bible illustrates how the internet can change the face of Bible translation. The detailed footnotes explaining the objective and subjective genitive differences and the scholars' discussion are only feasible with the internet platform. The instant updated nature and the ability to include much more information than the printed version make the notes of the NET bible outstanding. The difference between a commentary and a translation becomes blurred when the translation can include these kinds of notes.

It is exciting to realize how scholar debate can change the text of the Bible through new translations. The discussion among scholars is not only a murmur within the ivory tower, but a driving force for clearer and more accurate translations of the Holy texts used by the church. With the use of the internet, more translation projects can be done in shorter time with more people involved, providing more information and rationales for the translation than it used to be. This survey is just a beginning of the exploration of how scholar investigation can become the driving force for new renderings in Bible translations. More studies need to be done to explore further development and impact of the scholarly discussion on the translation decisions in the future.

\section{Bibliography}

Dart, J. (2011, October 17) Plain-talk Bible debuts with mainstream backing. Christian Century. Retrieved from http://www.christianitycentury.org.

Easter, M. C. (2010) The Pistis Christou debate: Main arguments and responses in summary. Currents in Biblical Research, 9(1), 33-37.

Hunn, D. (2010) Debating faithfulness of Jesus Christ in twentieth-century scholarship. In M. F. Bird and P. M. Sprinkle (Ed.), The faith of Jesus Christ: Exegetical, Biblical and theological studies (pp. 15-31). Peabody, MA: Hendrickson.

William Loader, Boris Repschinski, Eric Wong (Eds.)

Matthew, Paul, and Others: Asian Perspectives on New Testament Themes

(C) 2019 innsbruck university press, ISBN 978-3-903187-66-5, DOI 10.15203/3187-66-5 


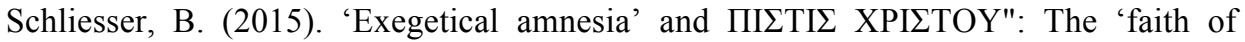
Christ' in nineteenth-century Pauline scholarship. The Journal of Theological Studies, 66(1). doi: 10.1093/jts/flv008.

Silliman, D. (2015, August 28) The most popular Bible of the year is probably not what you think it is. The Washington Post, August 28, Retrieved from https://www.washingtonpost.com.

Stec, D. (2004) Review: The Holy Bible: English Standard Version. Vetus Testamentum, 54(3): 421.

Zylstra, S. E. (2014, March 13) The most popular and fastest growing Bible translation isn't what you think it is: NIV vs. KJV. Christianity Today. Retrieved from http://www.christianitytoday.com. 
